\title{
Spontaneous duodenal fistulisation from walled-off pancreatic necrosis
}

\author{
Amit R Hudgi ㄷ, ${ }^{1}$ Michael John Coles, ${ }^{1}$ Isaac Perry, ${ }^{2}$ Kenneth J Vega ${ }^{2}$
}

${ }^{1}$ Internal Medicine, Augusta University Medical College of Georgia, Augusta, Georgia, USA ${ }^{2}$ Gastroenterology and Hepatology, Augusta University Medical College of Georgia, Augusta, Georgia, USA

\section{Correspondence to} Dr Amit R Hudgi; amithudgi@gmail.com

Accepted 3 February 2022

\section{DESCRIPTION}

Walled-off pancreatic necrosis (WOPN) is a known complication of pancreatitis. It can be complicated by infection, haemorrhage and, rarely, fistulisation. Here we present a rare case of WOPN with duodenal fistulisation.

A woman with medical history of type 2 diabetes mellitus, hypothyroidism, chronic kidney disease, morbid obesity (body mass index of 60) and heart failure presented to the emergency room with new-onset abdominal pain. She described the pain as sharp in nature, epigastric in location, 10/10 in severity, non-radiating as well as associated with nausea and vomiting. Of note, the patient was previously admitted to our hospital, approximately 6 weeks earlier, with similar symptomatology and diagnosed with diabetic ketoacidosis and acute pancreatitis. The patient was afebrile and tachycardic with other vital signs normal. Physical examination revealed a diffusely tender abdomen to palpation, limited by morbid obesity. Significant laboratory values included a white cell count of $9400 / \mathrm{mm}^{3}$, creatinine of $1.73 \mathrm{mg} / \mathrm{dL}$, glucose of $276 \mathrm{mg} / \mathrm{dL}$, albumin of $3.1 \mathrm{~g} / \mathrm{dL}$, erythrocyte sedimentation rate of $120 \mathrm{~mm} /$ hour and lipase of $78 \mathrm{U} / \mathrm{L}$. No signs of systemic illness were identified. CT scan of the abdomen showed a $10.6 \times 6.8 \times 9.5 \mathrm{~cm}$ region of WOPN (figure 1). It also revealed WOPN extending into the small bowel wall at the junction between the fourth portion of the duodenum and the ligament of Treitz (figure 1). Given mild symptomatology and low suspicion for infection, the patient was treated with conservative therapy

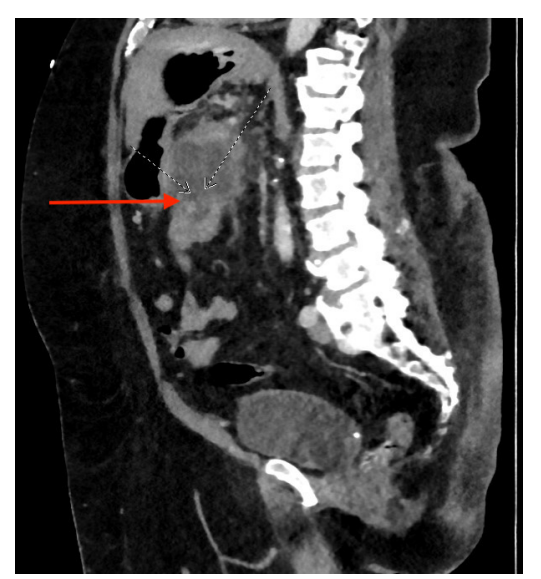

Figure 1 CT scan of the abdomen in the transverse view demonstrates a $10.6 \times 6.8 \times 9.5 \mathrm{~cm}$ region of walledoff pancreatic necrosis indicated by the red arrow. The fistula tract between the walled-off pancreatic necrosis and small bowel is indicated by the dashed white arrows.

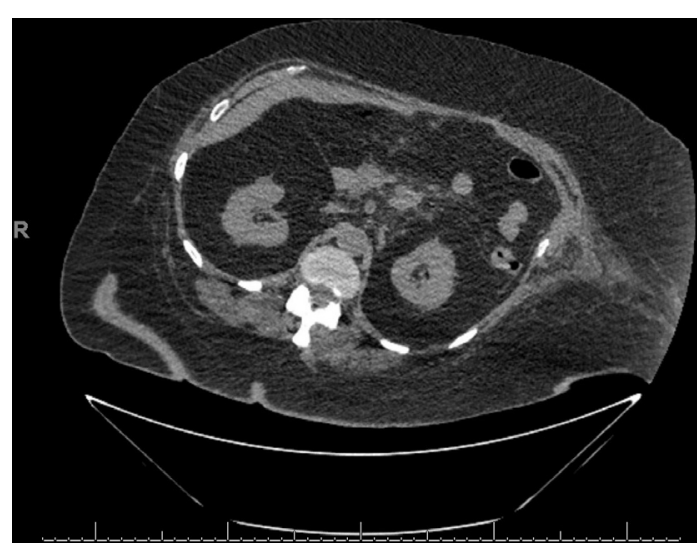

Figure 2 Follow-up CT scan of the abdomen in the transvere view showing complete resolution of the walled-off pancreatic necrosis with marked improvement in peripancreatic inflammatory changes.

with no emperic antibiotics. Over the course of the next few weeks, the patient had marked improvement in abdominal swelling with resolution noted on follow-up clinic evaluation. A repeat CT of the abdomen obtained 3 months later showed resolution of the WOPN as seen in figure 2 .

\section{Patient's perspective}

I am thankful for the care received and even more so with the need to not have to undergo surgical procedure for my fluid collection. I am more than happy to share my case with the medicine community if it will be providing learning opportunity. Kindly reach out to me after the acceptance of the article.

\section{Learning points}

- Patients presenting with abdominal pain who previously had a confirmed diagnosis of pancreatitis within the last 4 weeks should raise the triaging clinician's suspicion for walled-off pancreatic necrosis or a developing pancreatic fluid collection.

- Additionally, this case reinforces those enteric fistulae can be managed conservatively, if not infected, by allowing drainage into the bowel.

- Endoscopic intervention should only be considered in cases refractory to conservative therapy or if the patient demonstrates any clinical deterioration such as infection. 
WOPN is a significant complication of pancreatitis that occurs in approximately $15 \%$ of patients and typically within 4 weeks from the inciting inflammatory episode. ${ }^{1-3}$ It is defined as a heterogenous encapsulation of pancreatic and/or peripancreatic necrotic tissue with subsequent liquefaction. ${ }^{2-4}$ Most patients with WOPN are symptomatic, usually presenting with abdominal distention or pain, nausea, vomiting or jaundice. When infected, patients present with severe abdominal pain, fever and other signs of sepsis. Enteric fistulae are a rare complication of pseudocysts and, when present, typically occur at the transverse colon or splenic flexure. ${ }^{25}$ Duodenal fistulisation of WOPN is extremely rare, with few cases reported, and mainly result after superimposed infection of necrotic pancreatic material. ${ }^{46}$ This case reinforces those enteric fistulae can be managed conservatively, if not infected, allowing drainage into the bowel. Endoscopic intervention should only be considered in cases refractory to conservative therapy or if the patient demonstrates any clinical deterioration such as infection. This approach of minimal intervention and step-up approach has been shown to have lower complications and mortality. ${ }^{7}$

Acknowledgements We acknowledge some overlap of information between the current report and a published abstract presented at the American College of Gastroenterology Scientific Meeting in October 2021.

Contributors Conception and design, acquisition of data or analysis, and interpretation of data: ARH. Drafting the article or revising it critically for important intellectual content: ARH, MJC, IP and KJV. Final approval of the version published: $A R H, I P$ and KJV. Agreement to be accountable for the article and to ensure that all questions regarding the accuracy or integrity of the article are investigated and resolved: KJV.

Funding The authors have not declared a specific grant for this research from any funding agency in the public, commercial or not-for-profit sectors.

Competing interests None declared.

Patient consent for publication Consent obtained directly from patient(s).

Provenance and peer review Not commissioned; externally peer reviewed.

Case reports provide a valuable learning resource for the scientific community and can indicate areas of interest for future research. They should not be used in isolation to guide treatment choices or public health policy.

\section{ORCID iD}

Amit R Hudgi http://orcid.org/0000-0002-3062-7694

\section{REFERENCES}

1 Boškoski I, Costamagna G. Walled-off pancreatic necrosis: where are we? Ann Gastroenterol Q Publ Hell Soc Gastroenterol 2014;27:93.

2 Habashi S, Draganov PV. Pancreatic pseudocyst. World J Gastroenterol 2009;15:38-47.

3 Banks PA, Bollen TL, Dervenis C, et al. Classification of acute pancreatitis-2012: revision of the Atlanta classification and definitions by international consensus. Gut 2013:62:102-11.

4 Saadia R. Fistulas of the pancreas. surgical treatment: evidence-based and problemoriented. Munich: Zuckschwerdt, 2001.

5 Shatney $\mathrm{CH}$, Sosin $\mathrm{H}$. Spontaneous perforation of a pancreatic pseudocyst into the colon and duodenum. Am J Surg 1973;126:433-8.

6 Boopathy V, Balasubramanian P, Alexander T, et al. Spontaneous fistulisation of infected walled-off necrosis (won) into the duodenum in a patient following acute necrotising pancreatitis. Case Rep Child Meml Hosp Chic 2014;2014:bcr2013202863.

7 van Santvoort HC, Besselink MG, Bakker OJ, et al. A step-up approach or open necrosectomy for necrotizing pancreatitis. N Engl J Med 2010;362:1491-502.

Copyright 2022 BMJ Publishing Group. All rights reserved. For permission to reuse any of this content visit

https://www.bmj.com/company/products-services/rights-and-licensing/permissions/

BMJ Case Report Fellows may re-use this article for personal use and teaching without any further permission.

Become a Fellow of BMJ Case Reports today and you can:

- Submit as many cases as you like

- Enjoy fast sympathetic peer review and rapid publication of accepted articles

- Access all the published articles

Re-use any of the published material for personal use and teaching without further permission

Customer Service

If you have any further queries about your subscription, please contact our customer services team on +44 (0) 2071111105 or via email at support@bmj.com.

Visit casereports.bmj.com for more articles like this and to become a Fellow 